Helgoländer wiss. Meeresunters. 20, 229-248 (1970)

\title{
Potential bioassay of natural seawaters and influence of certain trace elements on the growth of phytoplankton organisms
}

\author{
A. A. Aleem \\ Oceanography Department, University of Alexandria; Alexandria, Egypt
}

KURZFASSUNG: Potentielles Bioassay natürlichen Meerwassers und Einfluß bestimmter Spurenelemente auf das Wachstum von Phytoplanktonorganismen. Zum Zweck einer Gütebeurteilung wurden Wasserproben, die aus dem Arrmelkanal und dem Atlantik südlich Irlands im Jahr $1949 \mathrm{zu}$ verschiedenen Jahreszeiten entnommen worden waren, mit N, P und Fe angereichert und durch Kulturen der Diatomeen Chaetoceros didymus, Phaeodactylum cornutum und einer nicht determinierten Cryptophyceen-Art getestet. Die Vermehrungsrate von Chaetoceros didymus diente als Kriterium zur Beurteilung der Wassergüte, die in Abhängigkeit von den Stationen und den Jahreszeiten erhebliche Unterschiede aufwies. Wasser aus dem Gebiet südlich Irlands induzierte im Test mit Chaetoceros didymus Auxosporenbildung, die durch Zugabe von $\mathrm{Cu}$ gehemmt werden konnte. Li-Zusatz zu natürlichem und künstlichem Seewasser bewirkte eine Verlängerung der Zellen von Chaetoceros didymus; der gleiche Effekt wurde auch bei entsprechenden Versuchen mit der Chlorophycee Stichococcus spec. festgestellt.

\section{INTRODUCTION}

The problem of "good" and "bad" seawater dates back to the classical culture experiments of Allen \& Nielsen (1910) and Allen (1914) at Plymouth (England), who suggested that natural seawater contains some substance or substances which are essential for the growth of diatoms. This hypothesis was tested by Matudaira (1939) in Japan, who made experiments on the physiological effects of different seawaters (collected at different depths and seasons) on the growth of diatoms. They enriched seawaters with $\mathrm{P}, \mathrm{Si}, \mathrm{Fe}$, inoculated them with diatom cultures and concluded that surface and bottom waters afforded better growth of diatoms than intermediate waters, while coastal water also maintained better growth than oceanic water.

De Valera (1940), likewise, found that waters from the Fucus-Ascopbyllum zone permit better development of zygotes of Enteromorpha than water from $30 \mathrm{~m}$ depth. H. KYLIN (1941, 1943, 1946), used germinating zygotes of Enteromorpha and Ulva species as the bioassay organisms of infertile water from $30 \mathrm{~m}$ depth to which various enrichments were added and found that such water was usually poor in $\mathrm{NO}_{3}$, $\mathrm{PO}_{4}$, Fe and Mn. A. KYLIN $(1943,1945)$ could improve the qualities of such water by 
addition of trace elements such as $\mathrm{Zn}, \mathrm{Mn}, \mathrm{Fe}$ and $\mathrm{Co}$; while $\mathrm{Ni}, \mathrm{Al}$ and $\mathrm{Cd}$ were inert. H. KYLIN thus ascribed the improvement of the infertile water to the addition of trace elements.

Meanwhile, Wilson (1951), working on the rearing of sea-urchin larvae and of two other marine worms in both Plymouth water and Celtic sea water (later also in water from the Clyde), found that Celtic water was more favourable than Plymouth water for better development of such organisms.

The problem of "good" and "bad" water has been acknowledged by zoologists at Plymouth, ever since RUSSELL (1935) published his original observations on plankton indicators of the qualities of different water masses, taking the Chaetognath, Sagitta elegans as being characteristic of "good" water, while $S$. setosa was taken as an indicator of "bad" water. It was also concluded that the water around Plymouth had become progressively comparatively infertile from the 1930's onwards.

The experiments described were undertaken at the Plymouth Laboratory in 1949 at the suggestion of Dr. W. H. HARveY, in an attempt to test the fertility of different waters, using phytoplankton species as bioassay organisms. Phytal organisms provide better test organisms, because they can be grown under controlled conditions, their growth can be more easily assessed, and their growth requirements are better known than those of invertebrate larvae.

Since then, a considerable amount of work has been published on the nutritional requirements of fresh water and marine phytoplankton organisms and references to these are found in the works of Provasoli $(1958,1963)$, Fogg (1965), Droop (1957, 1962, 1966), WrESSNER (1962) and others. Reference is also made to the bioassay experiments undertaken by JoHNSTON $(1963,1964)$, using Skeletonema costatum. It must be emphasized, however, that in all these experiments attention was given principally to the influence of organic substances such as vitamins and to that of chelating agents on growth, rather than to individual trace metals.

In our experiments at Plymouth, no organic substances were added to the culture media employed, and (since these cultures were nonaxenic) it is assumed that such substances are provided in the culture media by the bacterial flora which are associated with the phytoplankton organisms. Attention was also given to the possible improvement of the qualities of the so called "bad" waters by the addition of trace elements and interesting results were obtained, particularly with $\mathrm{Cu}$ and $\mathrm{Li}$.

No chelating agents were added to our culture media as with such substances it is difficult to test the influence on growth of individual trace metals.

\section{MATERIAL AND METHODS}

Organisms. The organisms employed in these experiments include three phytoplankton species (isolated by the writer from the Plymouth water) as well as a strain of AlLeN's original culture of Nitzschia closterium forma minutissima. This latter organism belongs, according to HENDEY (1954), to Phaeodactylum tricornutum BoHLIN. It has three morphological phases, viz. ovoid, fusiform and triradiate. 
The former three organisms isolated from the plankton are: (1) the pelagic diatom Chaetoceros didymus; (2) a green alga, Stichococcus sp. similar to that described by ButCHER (1957) as S. cylindricus; and (3) a reddish, small flagellate belonging to Cryptophyceae (referred to as flagellate " $A$ "). All these organisms were subcultured in artificial sea water.

The size of inoculum used was kept to a minimum $(0.05-0.1 \mathrm{ml})$, unless otherwise stated, in order to avoid the influence of the stock culture on the media employed. The initial concentration of cells in the waters assayed range between 20 to 50 cells $/ \mathrm{ml}$, unless otherwise stated.

Media. The artificial sea water used was made according to the formula of LyMan \& Fleming (in Sverdrup et al. 1942) and as modified by Chu (1946). A solution of the minor elements $\mathrm{Al}, \mathrm{Mn}, \mathrm{Ba}, \mathrm{Rd}, \mathrm{Li}, \mathrm{Fe}$ (as citrate), $\mathrm{Cu}, \mathrm{I}, \mathrm{As}, \mathrm{Zn}$ was prepared separately and $1 \mathrm{ml}$ of this (solution " $A$ ") was added, when required, to 11 of the solution of the major constituents. Solution " $A$ " was often replaced by a solution of Laminaria ash or soil extract. When testing the effect of individual trace elements, these were added separately. CHu (1946) had been able to grow the following diatoms in this type of artificial sea water: Asterionella japonica, Biddulphia mobiliensis, Chaetoceros didymus, Coscinodiscus excentricus, Ditylum brightwelli, Fragilaria striatula, Nitzschia seriata, Rhizosolenia alata, Streptotheca thamensis and Thalassiotbrix longissima.

The artificial sea water used at Plymouth had a salinity of ca. $33.4 \%$ and a $\mathrm{pH}$ of ca. 8. The following maximum impurities in the major constituents used (AR) are recorded as percentages of the molecular weights. This was essential to explain the growth of the test organisms which were often noticed occurring in a solution of the major constituents only.

I mpurities. Impurities in $\mathrm{NaCl}: \mathrm{SO}_{4}(0.003 \%), \mathrm{Ca}(0.005 \%), \mathrm{NO}_{3}$ $(0.002 \%), \mathrm{Mg}(0.005 \%), \mathrm{Pb}(0.001 \%), \mathrm{NH}_{3}(0.001 \%), \mathrm{Ba}(0.003 \%), \mathrm{Fe}$ $(0.0005 \%), \mathrm{As}_{2} \mathrm{O}_{3}(0.0001 \%)$. Impurities in $\mathrm{Na}_{2} \mathrm{SO}_{4} \cdot 10 \mathrm{H}_{2} \mathrm{O}: \mathrm{Cl}(0.0005 \%), \mathrm{Fe}$ $(0.0002 \%), \mathrm{NO}_{3}(0.001 \%), \mathrm{Zn}(0.0005 \%), \mathrm{NO}_{2}(0.0002 \%), \mathrm{NH}_{3}(0.0005 \%)$, $\mathrm{Pb}(0.0004 \%), \mathrm{As}_{2} \mathrm{O}_{3}(0.0002 \%)$. Impurities in $\mathrm{CaCl}_{2} \cdot 6 \mathrm{H}_{2} \mathrm{O}: \mathrm{SO}_{4}(0.005 \%)$, $\mathrm{Pb}(0.001 \%), \mathrm{NO}_{3}(0.002 \%), \mathrm{Fe}(0.0005 \%), \mathrm{PO}_{4}(0.001 \%), \mathrm{Ba}, \mathrm{Sr}(0.01 \%), \mathrm{SiO}_{2}$ $(0.002 \%), \mathrm{As}_{2} \mathrm{O}_{3}(0.0001 \%)$. Impurities in $\mathrm{KCl}: \mathrm{SO}_{4}(0.003 \%), \mathrm{Ba}(0.003 \%), \mathrm{NO}_{3}$ $(0.002 \%), \mathrm{Ca}(0.005 \%), \mathrm{Pb}(0.001 \%), \mathrm{Mg}(0.005 \%), \mathrm{Fe}(0.0005 \%), \mathrm{NH}_{3}(0.001 \%)$, moisture $(0.3 \%)$. Impurities in $\mathrm{NaHCO}_{3}: \mathrm{Na}_{2} \mathrm{CO}_{3}(1 \%), \mathrm{Pb}(0.001 \%), \mathrm{Cl}(0.005 \%)$, $\mathrm{Fe}(0.0005 \%), \mathrm{SO}_{4}(0.005 \%), \mathrm{Ca}, \mathrm{Mg}$ etc. $(0.01 \%), \mathrm{NO}_{3}(0.002 \%), \mathrm{NH}_{3}(0.0005 \%)$, $\mathrm{SiO}_{2}(0.01 \%), \mathrm{I}(0.006 \%), \mathrm{As}_{2} \mathrm{O}_{3}(0.0001 \%)$. Impurities in $\mathrm{H}_{3} \mathrm{BO}_{3}: \mathrm{Cl}(0.0002 \%)$, $\mathrm{Fe}(0.0005 \%), \mathrm{SO}_{4}(0.002 \%), \mathrm{Ca}(0.002 \%), \mathrm{Pb}(0.001 \%), \mathrm{As}_{2} \mathrm{O}_{3}(0.0001 \%)$. Impurities in $\mathrm{KBr}: \mathrm{Cl}(0.25 \%), \mathrm{SO}_{4}(0.01 \%)$, Bromate $(0.001 \%)$, Heavy metals $(0.001 \%)$, Iodide $(0.05 \%), \mathrm{Fe}(0.0005 \%)$, Moisture $(0.5 \%)$.

Enrichment. Natural sea water as well as artificial sea water used for bioassay experiments were initially enriched with $\mathrm{N}, \mathrm{P}, \mathrm{Fe}$ in the following concentrations: $\mathrm{NaNO}_{3}\left(2000 \mathrm{mg} / \mathrm{m}^{3}\right), \mathrm{NaHPO}_{4}\left(200 \mathrm{mg} / \mathrm{m}^{3}\right)$ and $\mathrm{Fe}$ (as ferric citrate) $\left(5 \mathrm{mg} / \mathrm{m}^{3}\right)$. When testing the influence of $\mathrm{Cu}$ and $\mathrm{Li}$ on growth, these two metals were added as $\mathrm{CuSO}_{4}$ and $\mathrm{LiCl}$.

Characteristics of the natural sea waters. Bioassays were 
made on Plymouth waters from outside the breakwater and collected in February, March and July, 1949. These will be referred to as "outside" or $\mathrm{E}_{1}$ (Eddystone) waters. Such waters are compared with those taken from the Celtic Sea and collected in March, May and July, 1949. These will be referred to as $8^{\circ} \mathrm{W}$ or Celtic waters. The characteristics of certain of these waters are given by WILsoN (1951) and are summarized as follows:

(1) Celtic Sea $\left(8^{\circ} \mathrm{W}\right)$ water of March: Position $50^{\circ} 36^{\prime} \mathrm{N} \& 8^{0} 04^{\prime} \mathrm{W}$ (over Labadie Bank). Vertical mixing should have been possible. Plankton (night): abundant Sagitta elegans, large Aglantha, Euphausians. No sign of phytoplankton. Physical and Chemical $(0-5 \mathrm{~m})$ : Temperature $9.95^{\circ} \mathrm{C}$; S $35.24 \%$; Phosphate (organic 0.18; inorganic 0.51 ; total $0.69 \mathrm{mg}$ at $\left./ \mathrm{m}^{3}\right)$.

(2) Outside ( $\left.E_{1}\right)$ water of March: Exact position unknown. Plankton (day): very, very sparse; no sign of phytoplankton. 1 Sagitta setosa present. Physical and Chemical (at $\mathrm{E}_{1}$ [Eddystone] surface): Temperature $10.1^{\circ} \mathrm{C}$; S $35.38 \%$; Phosphate (organic 0.08 ; inorganic 0.43 ; total $0.51 \mathrm{mg}$ at $/ \mathrm{m}^{3}$ ).

(3) Outside $\left(E_{1}\right)$ of February: Characteristics unknown.

(4) Celtic water of May (collected by pump from $20 \mathrm{~m}$ ): Position $49^{\circ} 44^{\prime} \mathrm{N} \&$ $8^{\circ} 50^{\prime} \mathrm{W}$. Plankton (night): rich in zooplankton and Phaeocystis. Physical and Chemical: Temperature $11.50^{\circ} \mathrm{C}$; S $35.36 \%$; phosphate (organic 0.22 ; inorganic 0.12 ; total $\left.0.34 \mathrm{mg} \mathrm{at} / \mathrm{m}^{3}\right)$.

(5) Outside $\left(\mathrm{E}_{1}\right)$ water of July: Rich in zooplankton; other characteristics not recorded.

(6) Celtic water of July: Characteristics unknown.

Copper content of nat u ral waters. Natural seawaters were filtered through clean Brekefeld filter candles, followed by fine grade Whatman filter paper. $\mathrm{Cu}$-content was determined according to the method employed by Atkins (1933), utilizing the colour test obtained by diethyl-dithio carbamate. Results are shown as follows: (1) Celtic water of March: no colour developed. (2) $E_{1}$ water of March: no colour developed. (3) $E_{1}$ water of February: $30 \mathrm{mg} / \mathrm{m}^{3}$ before ageing; $2-4 \mathrm{mg} / \mathrm{m}^{3}$ after ageing. (4) Celtic water of May: $8-10 \mathrm{mg} / \mathrm{m}^{3}$. (5) $\mathrm{E}_{1}$ water of July: $2 \mathrm{mg} / \mathrm{m}^{3}$. (6) Celtic water of July: $2 \mathrm{mg} / \mathrm{m}^{3}$. (7) Artificial sea water: $6-8 \mathrm{mg} / \mathrm{m}^{3}$.

It has also been observed that storing sea water in glass carboys in the dark for 1-2 months results in a reduction of its copper content as occurred in the case of Plymouth water of February.

$\mathrm{Cu} \mathbf{t} \mathrm{ure}$ conditions. All glassware and vessels employed were of Pyrex glass. They were thoroughly washed with chromic acid, tap water and distilled water. Double-distilled water was used for the preparation of antificial sea water. All chemicals used were A.R.; their maximum impurities were recorded. Culture flasks of 100 to $200 \mathrm{ml}$ capacity were used. Usually, 25 to $50 \mathrm{ml}$ of the medium was placed in each flask and, after inoculation, the flasks were plugged with cotton wool. Duplicate experiments were usually made. Culture media were sterilized by heating to $65^{\circ} \mathrm{C}$, cooled and then aerated by shaking.

From March to the middle of July, cultures were kept exposed to a North window at room temperature. As from July 17th, the cultures made were kept in a constant temperature room at $15^{\circ} \pm 0.2^{\circ} \mathrm{C}$, exposed to continuous fluorescent "day- 
light" illumination of 4,000-5,000 Lux. No mechanical shaking was employed, but the culture flasks were carefully shaken at frequent intervals.

Assessment of growth. Growth was assessed by counting aliquot samples in a haemocytometer and/or in a $1 \mathrm{ml}$ graduated counting cell. Counts were usually made 7-10 days following inoculation. Growth was usually observed for longer or shorter intervals for about 2 months. Over 40 random counts were made each time. The standard deviation was in the range of \pm 10 to $15 \%$ of the mean. The relative growth constant $(\mathrm{k})$ of Chaetoceros didymus in the different sea waters was used as an index to classify such waters according to their degree of "fertility". This was obtained according to the formula:

$$
\mathrm{k}=\frac{2 \cdot 3}{\mathrm{t}}\left(\log \mathrm{N}_{\mathrm{T}}-\log \mathrm{N}_{0}\right)
$$

where $\mathrm{N}_{0}=$ number of cells/unit volume at time $\mathrm{O}, \mathrm{N}_{\mathrm{T}}=$ number of cells/unit volume at time $\mathrm{T}$, and $\mathrm{t}=$ time in days.

\section{RESULTS}

Growth of Chaetoceros didymus in $\mathrm{E}_{1}$, and in Celtic sea waters collected in March

The results of this experiment are shown in Figure 1. Although both waters were enriched with $\mathrm{N}, \mathrm{P}, \mathrm{Fe}$, no growth occurred in the Plymouth water, and both waters were poor in $\mathrm{Cu}$. The addition of $10 \mathrm{mg} \mathrm{Cu} / \mathrm{m}^{3}$ to the Plymouth water resulted in a slight improvement in growth of Chaetoceros didymus (from 20 cells $/ \mathrm{ml}$ to 1,400 cells/ml in 10 days).

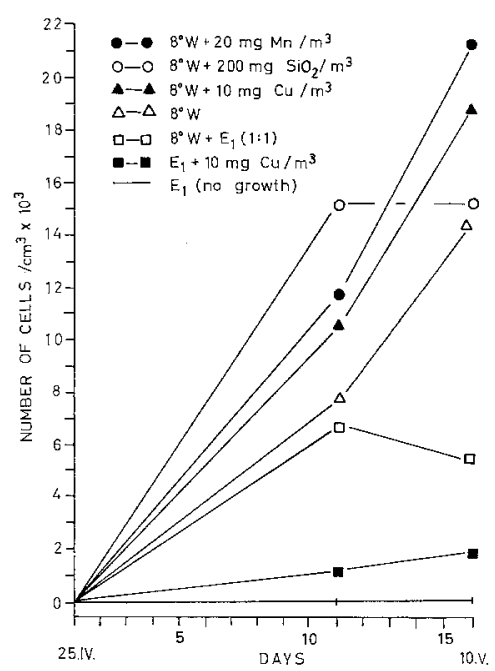

Fig. 1: Growth of Chaetoceros didymus in outside sea water Plymouth $\left(\mathrm{E}_{1}\right)$ and Celtic water $\left(8^{\circ} \mathrm{W}\right)$ both collected in March 
Conversely, good growth was obtained in Celtic sea water (from 20 cells $/ \mathrm{ml}$ to 7,900 cells $/ \mathrm{ml}$ in 10 days). The crop of Chaetoceros didymus in this water averaged 36,250 cells $/ \mathrm{ml}$ in three weeks (not shown in Fig. 1).

The addition of $10 \mathrm{mg} \mathrm{Cu} / \mathrm{m}^{3}$ to the Celtic water further improved its qualities, which resulted in a crop of 10,750 cells $/ \mathrm{ml}$ after 10 days and about $19,000 \mathrm{cells} / \mathrm{ml}$ after 2 weeks. Addition of traces of $\mathrm{Mn}$ and $\mathrm{SiO}_{2}$ to the Celtic water had an effect similar to that of $\mathrm{Cu}$.

Mixing equal quantities of the "infertile" Plymouth water and the "fertile" Celtic water improve the quality of the Plymouth water; however, growth declined after 10 days.

These cultures had been further observed and it was interesting to notice that a slight growth (300 cells $/ \mathrm{ml})$ occurred in the Plymouth water (without additives) 3 weeks after the beginning of the experiment. This could be explained, (a) either by the secretion in the medium of a substance essential for growth by the bacterial flora or (b) to the elimination of some toxic substance in the infertile water. Cells grown in a mixture of the two waters showed a tendency to form auxospores.

The results of this experiment demonstrate clearly that the Celtic water collected in March was much more favourable for the growth of Chaetoceros didymus, than the Plymouth water collected in the same month; furthermore, the properties of both waters were improved by the addition of traces of $\mathrm{Cu}$.

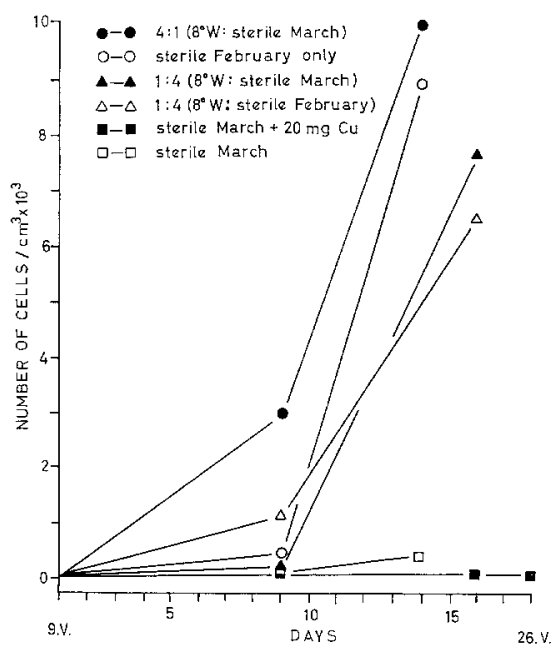

Fig. 2: Growth of Chaetoceros didymus in mixture of outside sea water ( $\mathrm{E}_{1}$ February and March) with $8^{0}$ West water collected in March

Effect of mixing "sterile" waters of Plymouth collected in February and March, with "fertile" Celtic water of March

This experiment was made with mixtures of aged waters as follows: (a) $\mathrm{E}_{1}$ water of February stored for about 3 months, (b) $E_{1}$ water of March stored for about 2 months 
and (c) Celtic water $\left(8^{\circ} \mathrm{W}\right.$ ) collected in March and stored for about 2 months (in the proportions shown in Fig. 2).

The results after 8 days showed little or no improvement when using Plymouth water of March or with a mixture with $8^{\circ} \mathrm{W}$ water added in the proportion of $4: 1$. The "sterile" water of Plymouth collected in February showed a better result (during the same period) when mixed, using the same proportions with Celtic water of March. When the latter water was added to the sterile water of March in the proportion of $4: 1$, substantial growth was noticed and auxospores were also formed.

Figure 2 also shows a rather long lag period when using the above mixtures, as well as when using February water alone, after which exponential growth took place. Moreover, addition of $20 \mathrm{mg} \mathrm{Cu} / \mathrm{m}^{3}$ to the sterile water of March yielded no growth in 17 days. It is notable that while in experiment (1) Plymouth water of March yielded no growth for 3 weeks, the same water without additives improved slightly in experiment (2) yielding 350 cells $/ \mathrm{ml}$ in 2 weeks. This may have been due to the further ageing of this water.

\section{Effect of $\mathrm{Cu}$ on the Celtic water of March}

Cultures were made of Celtic water of March, enriched as usual with $\mathrm{N}, \mathrm{P}, \mathrm{Fe}$ and the following concentrations of $\mathrm{Cu}$ were added successively: $5,10,25,50$, $100 \mathrm{mg} / \mathrm{m}^{3}$. These media were inoculated with Chaetoceros didymus from a previous

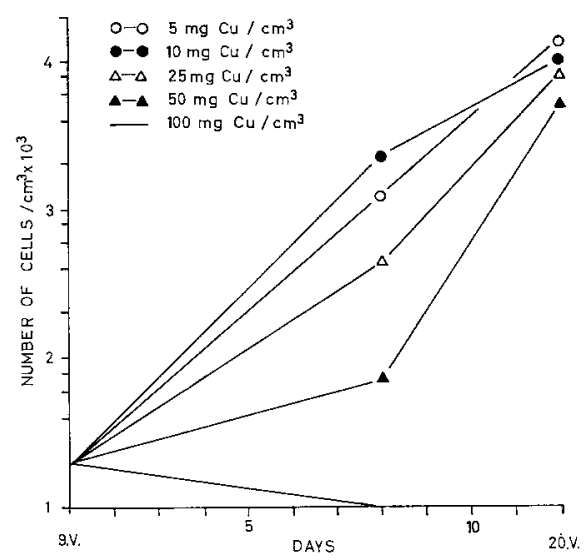

Fig. 3: Influence of copper on growth of Chaetoceros didymus in Celtic water $\left(8^{\circ} \mathrm{W}\right)$ collected in March

culture grown in the same water with no $\mathrm{Cu}$ added. The results are shown logarithmically in Figure 3. Concentrations of 5 to $25 \mathrm{mg} \mathrm{Cu} / \mathrm{m}^{3}$ had a stimulating effect on the growth of $C$. didymus. The crops obtained after one week could be arranged in a descending order according to the following concentrations of $\mathrm{Cu}: 10,5,25 \mathrm{mg} / \mathrm{m}^{3}$. 
The maximum crop after 11 days was, however, obtained in cultures to which $5 \mathrm{mg}$ $\mathrm{Cu} / \mathrm{m}^{3}$ were added, and yielded an average of 13,000 cells $/ \mathrm{ml}$.

A long lag period was obtained with $50 \mathrm{mg} \mathrm{Cu} / \mathrm{m}^{3}$, after which exponential growth started. This has often been observed when using such concentrations both in natural and in artificial sea water and could be due either to adsorption of the heavy metal on glass, on organic matter or on bacteria in the medium; or to the adjustment of the remaining viable cells of Chaetoceros didymus to the new culture conditions or due to the effects of both.

No growth was obtained with $100 \mathrm{mg} \mathrm{Cu} / \mathrm{m}^{3}$. It is notable that traces of $\mathrm{Cu}$ inhibited auxospore formation of the Chatoceros didymus grown in Celtic water of March.

\section{Growth of Chaetoceros in Celtic sea water collected in May}

Celtic sea water collected in May and enriched with $\mathrm{N}, \mathrm{P}, \mathrm{Fe}$, yielded poor growth with Chaetoceros didymus. The number of cells increased from $60 / \mathrm{ml}$ to $1,900 / \mathrm{ml}$ in 3 weeks. A large number of the cells counted were auxospores. Addition of traces of $\mathrm{Cu}$ to this water almost doubled the growth in the same period, but inhibited auxospore formation.

\section{Growth of Chaetoceros in Plymouth water and in Celtic} water both collected in July and influence of $\mathrm{Cu}$

Both waters were initially poor in $\mathrm{Cu}$. Cultures were started on July 20th. Both waters were enriched as usual with N, P, Fe. Each culture vessel was inoculated with $0.25 \mathrm{ml}$ of a stock culture of Chaetoceros didymus (which had been grown in artificial sea water) thus providing a concentration of 320 cells $/ \mathrm{ml}$ in each flask, and kept under

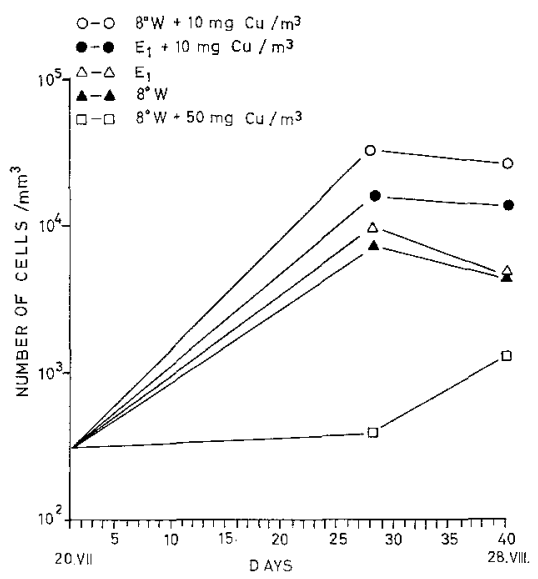

Fig. 4: Growth of Cbaetoceros didymus in outside $\left(\mathrm{E}_{1}\right)$ and Celtic waters collected in July 
constant temperature and illumination. The results of this experiment are shown on a logarithmic scale in Figure 4.

Plymouth water was only slightly more favourable than the Celtic sea water for the growth of Chaetoceros didymus, but no auxospores were formed in this medium. The Celtic sea water favoured the formation of auxospores, and C. didymus gametes* were observed prior to the formation of auxospore.

Addition of traces of $\mathrm{Cu}$ further stimulated the growth of Chaetoceros didymus in both waters, but inhibited auxospore formation in the Celtic sea water. A long lag period was observed in cultures which utilized Celtic water to which $50 \mathrm{mg} \mathrm{Cu} / \mathrm{m}^{3}$ had been added.

\section{Effect of Li on the growth of Chaetoceros in Celtic water and in Plymouth water of July}

Conditions of this experiment are the same as in the last experiment, with the exception that $\mathrm{Cu}$ was replaced by Li. Growth of Chaetoceros didymus in Plymouth $\left(E_{1}\right)$ water of July was improved by the addition of $10 \mathrm{mg} \mathrm{Li} / \mathrm{m}^{3}$, whereby cells increased in number from $320 / \mathrm{ml}$ to 37,500 cells $/ \mathrm{ml}$ in 4 weeks. This growth is comparable to that in Celtic water to which was added $10 \mathrm{mg} \mathrm{Cu} / \mathrm{m}^{3}$ (Fig. 4). Lithium, however, had another important effect, causing elongation of cells of C. didymus, whether added in traces to natural or to artificial sea water. Cells up to 5 times longer than usual were noticed in such cultures.

The effect of $\mathrm{Li}$ was also tested in cultures utilizing Celtic water of July to which the following concentrations were added: $5,10,20,50,100 \mathrm{mg} / \mathrm{m}^{3}$. In these cultures there were no substantial differences in the crop of Chaetoceros didymus after 4 weeks; the numbers of cells yielded, thus ranged between $7,000-9,000 / \mathrm{ml}$. The only difference between these cultures and the control cultures, when utilizing the same water with no $\mathrm{Li}$ added, is the elongation of cells when the $\mathrm{Li}$ is added. Auxospore formation in Celtic water of July was not inhibited by the addition of $\mathrm{Li}$, and $\mathrm{Li}$ in concentrations up to $100 \mathrm{mg} / \mathrm{m}^{3}$ does not seem toxic to C. didymus.

Growth of Phaeodactylum tricornutum in different sea waters

Phaeodactylum tricornutum (from a stock culture in artificial sea water) was inoculated into culture flasks containing the following media, all enriched, as usual, with $\mathrm{N}, \mathrm{P}, \mathrm{Fe}$ :

(1) Plymouth $\left(E_{1}\right)$ water of February, (2) Plymouth $\left(E_{1}\right)$ water of March, (3) Celtic water of May, (4) a mixture (1:1) of Plymouth water of March and Celtic water of May and (5) artificial sea water with Laminaria ash.

* Such structures, although observed at the time of the experiment, could be identified only after a visit to Helgoland, where Professor von STOSCH was making his earlier observations on the sexuality of centric diatoms. 
These cultures were kept for about one month. The results of the final crop are shown in Table 1. The above media could be classified in a descending order, according to the crop of Phaeodactylum tricornutum obtained.

Table 1

"Fertility" of different waters as assayed by Phaeodactylum tricornutum

\begin{tabular}{|lc|}
\hline Type of water & $\begin{array}{c}\text { Crov obtained in 26 days } \\
\left(\mathrm{cells} / \mathrm{mm}^{3}\right)\end{array}$ \\
\hline Celtic water (May) & 970 \\
Artificial sea water & 760 \\
+ Laminaria ash & \\
Celtic water (May) & 651 \\
+ Plymouth water (March) (1:1) & 387 \\
Plymouth water (February) & 192 \\
\hline Plymouth water (March) & \\
\hline
\end{tabular}

The results of this experiment show clearly that Plymouth water of March is the least favourable for growth, followed by the February water, while the Celtic water gave the best results. Artificial sea water to which Laminaria ash is added approaches in its effect the Celtic water of May.

\section{Effect of $\mathrm{Cu}$ on the growth of Phaeodactylum tricornutum in Celtic water of May}

In this experiment concentrations of $\mathrm{Cu}: 5,10,20,50,100 \mathrm{mg} / \mathrm{m}^{3}$ were added to Celtic sea water of May, enriched with N, P, Fe. Inoculation was made of a previous culture grown in the same water. The initial concentration of cells in the culture flasks amounted to $4.4 / \mathrm{mm}^{3}$. These cultures were kept under constant temperature and illumination. The results are shown in Figure 5. Counts made after 12 days of inoculation showed that the best growth was obtained in cultures without addition of $\mathrm{Cu}$ (control); these yielded ca. 100 fold the number of cells inoculated. This may be explained by the fact that the original $\mathrm{Cu}$ concentration in the water $\left(8-10 \mathrm{mg} / \mathrm{m}^{3}\right)$ was adequate. After about 12 more days, the best crop was obtained from cultures to

Table 2

Relative growth-constants of Pbaeodactylum tricornutum in Celtic water of May with different $\mathrm{Cu}$ concentrations

\begin{tabular}{|cl|}
\hline Concentration & $\mathrm{k}$ \\
\hline Control & 0.52 \\
$5 \mathrm{mg} \mathrm{Cu} / \mathrm{m}^{3}$ & 0.32 \\
$10 \mathrm{mg} \mathrm{Cu} / \mathrm{m}^{3}$ & 0.30 \\
$20 \mathrm{mg} \mathrm{Cu} / \mathrm{m}^{3}$ & 0.25 \\
$50 \mathrm{mg} \mathrm{Cu} / \mathrm{m}^{3}$ & 0.18 \\
$100 \mathrm{mg} \mathrm{Cu} / \mathrm{m}^{3}$ & 0.0 \\
\hline
\end{tabular}


which $5 \mathrm{mg} \mathrm{Cu} / \mathrm{m}^{3}$ had been added. After this period growth more or less declined. With 50 and $100 \mathrm{mg} \mathrm{Cu} / \mathrm{m}^{3}$ growth was almost insignificant after a long lag period. Such high concentrations of $\mathrm{Cu}$ had an influence on the morphology of this species;

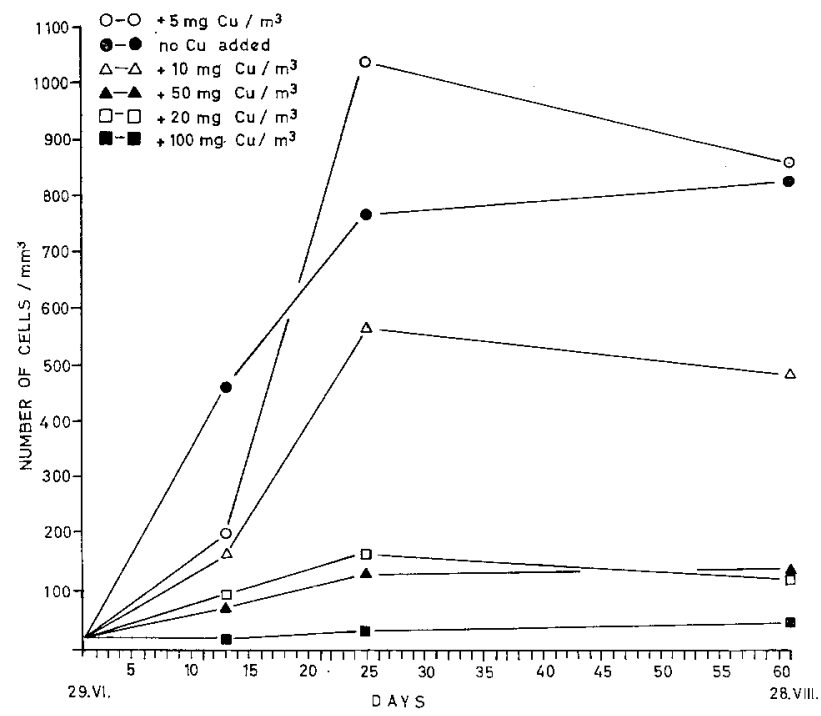

Fig. 5: Influence of copper on growth of Phaeodactylum tricornutum in $8^{\circ} \mathrm{W}$ (May)

cells tended to aggregate in clumps and the ovoid form predominated over the fusiform or triraidate forms of cells. Table 2 shows the relative growth constants of this species in different $\mathrm{Cu}$ concentrations after 12 days.

\section{Bioassay of different sea waters with flagellate "A"}

Flagellate " $A$ " was grown successively in Plymouth $\left(E_{1}\right)$ water of February and of March; in Celtic water of May; in artificial sea water minus the minor constituents; and in artificial sea water in which trace elements were replaced by Laminaria ash in solution. All media were enriched with $\mathrm{N}, \mathrm{P}, \mathrm{Fe}$. The inoculum had been previously grown in artificial sea water. The media could be graded in a descending order as follows: (1) Artificial sea water + Laminaria ash, (2) artificial sea water - minor constituents, (3) Celtic water of May, (4) Plymouth water of February, (5) Plymouth water of March.

The same organism also grew well in Plymouth water and in Celtic water which had been collected in July. This flagellate seems to tolerate higher concentrations of $\mathrm{Cu}$ or $\mathrm{Li}$ in the medium, because cultures made in Celtic water to which $50 \mathrm{mg} \mathrm{Cu} / \mathrm{m}^{3}$ had been added yielded a crop of 150,000 cells $/ \mathrm{ml}$ in 4 weeks. Addition of as much as $100 \mathrm{mg} \mathrm{Li} / \mathrm{m}^{3}$ to the same water appears to be tolerable. Cultures made of Plymouth water of July to which $5-100 \mathrm{mg} \mathrm{Li} / \mathrm{m}^{3}$ had been added, yielded crops varying be- 
tween $32,000-80,000$ individuals/ $\mathrm{ml}$ in 4 weeks. In these cultures the concentrations of cells do not proportionally follow the concentrations of the Li added.

\section{Growth of Stichococcus sp. in artificial sea water}

This green alga was not used as a bioassay organism for different sea waters. It grew fairly well, nonaxenically, in artificial sea water without the minor elements. In this experiment investigations were made on the influence of $\mathrm{Cu}$ and $\mathrm{Li}$ on the growth of this alga in artificial sea water. For this reason artificial sea water consisting

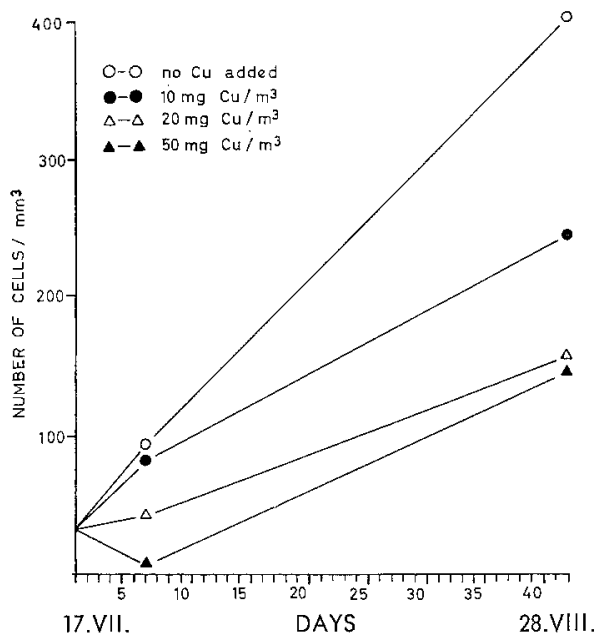

Fig. 6: Influence of copper on growth of Stichococcus sp. in A.S.W. enriched with N, P, Fe

of the major constituents and enriched with $\mathrm{N}, \mathrm{P}, \mathrm{Fe}$ was used. The following concentrations of $\mathrm{Cu}$ or $\mathrm{Li}$ were added separately: $\mathrm{Cu}: 0,10,20,50 \mathrm{mg} / \mathrm{m}^{3}, \mathrm{Li}: 0,5,10$, $20,50,100 \mathrm{mg} / \mathrm{m}^{3}$.

Culture flasks were inoculated with $0.5 \mathrm{ml}$ of a stock culture (grown in artificial sea water devoid of minor constituents) and the initial number of cells in each flask was about $32 / \mathrm{mm}^{3}$. The results which show the influence of $\mathrm{Cu}$ are illustrated in Figure 6. This alga seems to be sensitive to $\mathrm{Cu}$ in low concentrations, best growth was obtained without addition of Cu. Lower crops were obtained with 10 and $20 \mathrm{mg}$ of $\mathrm{Cu} / \mathrm{m}^{3}$, while $50 \mathrm{mg} \mathrm{Cu} / \mathrm{m}^{3}$ seems to inhibit growth; the number of living cells which were observed after 6 days was minimum. However, about a month later, the growth increased to about $130 \mathrm{cells} / \mathrm{mm}^{3}$. A possible explanation for the lag period and the rise in the growth curve with $50 \mathrm{mg} \mathrm{Cu} / \mathrm{m}^{3}$ was mentioned previously.

Conversely Stichococcus sp. seems to tolerate up to $100 \mathrm{mg} / \mathrm{m}^{3}$ of $\mathrm{Li}$. As in the case of Flagellate " $A$ ", the magnitude of crop obtained with the different concentrations of $\mathrm{Li}$ (Fig. 7) does not proportionally follow such concentrations. Li, however, causes elongation of cells of Stichococcus sp. as is also the case with Chaetoceros didymus. 


\section{Effect of different trace elements on the growth of Chaetoceros didymus in artificial sea water}

The artificial sea water employed was the same as in the last experiment (minor constituents omitted), it was also enriched with $\mathrm{N}, \mathrm{P}, \mathrm{Fe}$, and the following other enrichments were added separately: (1) Artificial sea water + soil extract, (2) artificial sea water $+\mathrm{Li}$ (traces), (3) artificial sea water $+\mathrm{Mn}$ (traces), (4) artificial sea water $+\mathrm{Cu}$ (traces), (5) artificial sea water $+\mathrm{Zn}$ (traces), (6) artificial sea water + drops of solution " $A$ " and (7) artificial sea water + As.

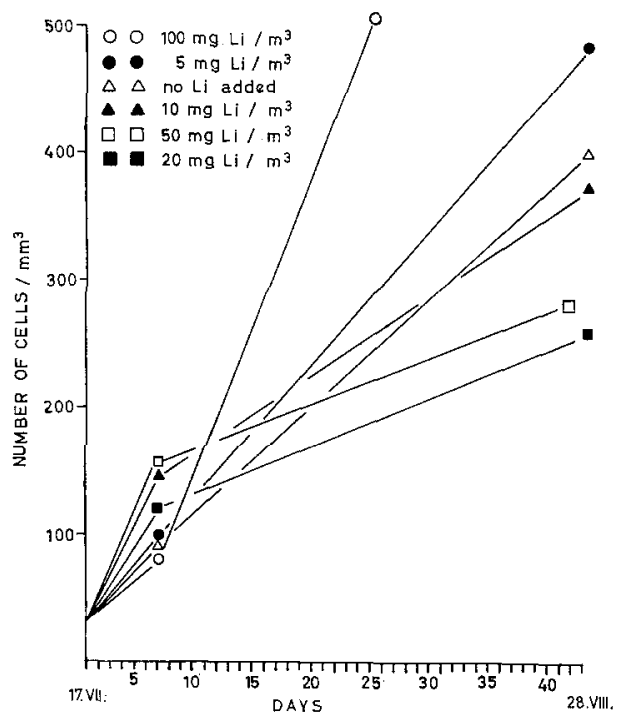

Fig. 7: Influence of $\mathrm{Li}$ on growth of Stichococcus sp. in A.S.W.

The Chaetoceros didymus inoculated, grew in Celtic water of May; the initial concentration in each culture vessel was about $20 \mathrm{cells} / \mathrm{ml}$. These cultures were observed for two months, and the results are reproduced in Figure 8. This figure shows that no growth occurred in artificial sea water (control) for almost 4 weeks. After such a very long lapse of time, growth occurred and, by the end of the experimental period, the number of cells attained ca. $4,000 / \mathrm{ml}$.

Traces of As inhibited growth completely and there seems to be no recovery under the influence of this metal. $\mathrm{Zn}$ had a little stimulating effect on growth during 4 weeks; such cultures were not followed later on. Both Laminaria ash and solution " $A$ " (mixture of minor elements) had more or less the same effect, but the final crop, after 2 months, was higher with Laminaria ash than with solution " $A$ ". Traces of Mn resulted in better growth than either of these two latter media. $\mathrm{Li}$ also stimulated growth (similar to that of $\mathrm{Mn}$ ) but the final crop was less than that obtained with $\mathrm{Mn}$.

The best crop was, undoubtedly, obtained in cultures to which soil extract had been added. Due to the complex nature of soil extract, its richness in trace elements 
and, probably, to its chelating capacity. The relative growth constant of Chatoceros didymus in this medium amounts to 0.41 and compares favourably with the "good" natural waters.

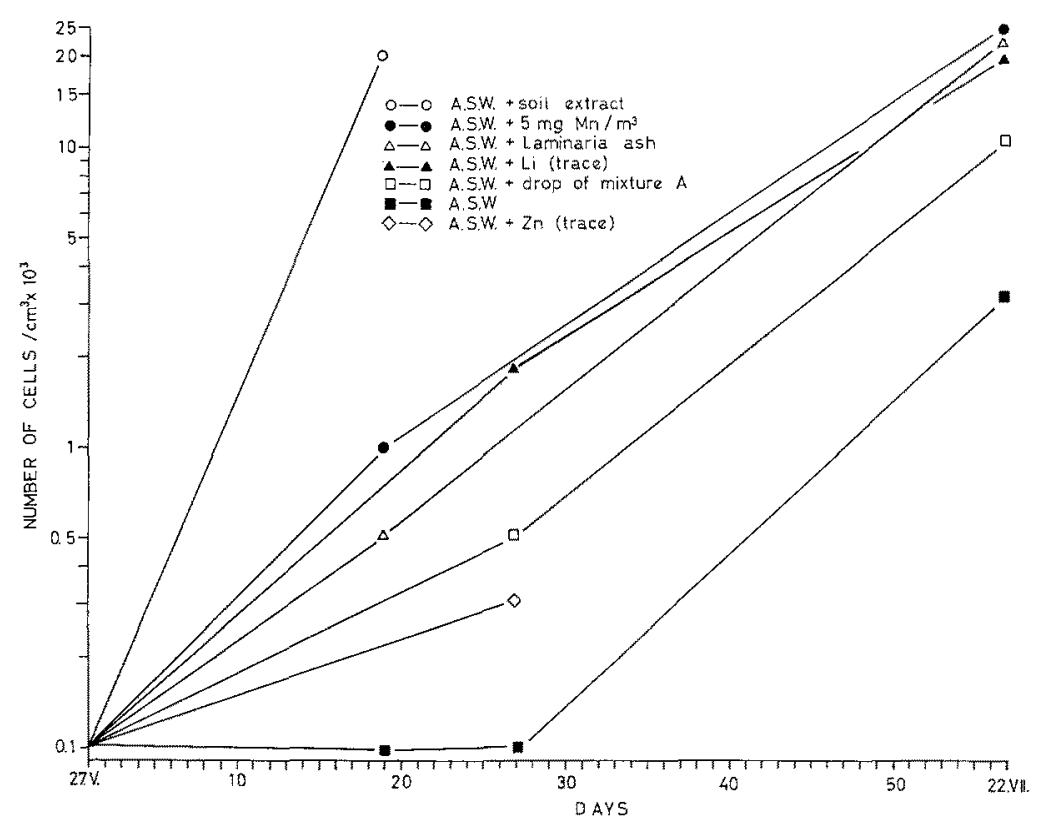

Fig. 8: Growth of Chatoceros didymus in artificial sea water with different trace elements

\section{DISCUSSION}

WILSON (1951) worked on the development of eggs and larvae of Echinus esculentus, Opheliabicornis and Sabellariaalveolata in waters from the Plymouth area (English Channel, Eddystone or $\mathrm{E}_{1}$ station) and in waters from the Celtic Sea sampled at different seasons. He discovered that the Celtic Sea waters were more favourable for healthy development of these organisms and concluded that the Channel water lacked some unknown constituent, essential for development, which was present in the Celtic Sea. WILSON repeated his experiments for a number of successive years (cf. WILSON \& ARmstrong 1952-1961) and concluded that English Channel water was not always an unfavourable medium and that, in one instance, growth improved with the addition of small amounts of copper. Addition of antibiotics; filter sterilization; variation of $\mathrm{pH}$; the addition of vitamin $\mathrm{B}_{12}$, ascorbic acid or a metal-chelating agent (EDTA); etc., did little to improve bad water for the afore-mentioned organisms (WILson \& ARMSTRONG 1954, 1958). However, a mixture of good and bad water improved the quality of bad water. This suggested that it is the presence of some beneficial substances in the good water rather than a toxic substance in the bad water which makes 
the difference. WILSON \& ARMSTRONG, therefore, made extracts with activated carbon and acetone of the bad and good waters, but such a procedure gave confusing results.

The difficulty of assaying good and bad waters by rearing larvae as used by Wilson (1951) has been demonstrated by Provasoli (1963). In fact, little is known about the physiological and nutritional requirements of such organisms and several other factors might interfere, and, the results obtained are mostly qualitative.

On the other hand, the use of phytoplankton as bioassay organisms gives more precise results. The nutritional requirements of such organisms and a good deal of their physiology and metabolism are fairly well known, and it is easy to count them and assay their crop.

The experiments quoted were made in 1949 at the Plymouth Laboratory using waters collected at different months both from outside the breakwater and from the Celtic Sea around $8^{\circ} \mathrm{W}$. These waters are the same as were used by WILson in his rearing experiments. These waters were bioassayed by using a pelagic diatom viz. Chaetoceros didymus, by Phaeodactylum tricornutum as well as by a cryptophycean "flagellate A". A green alga, viz. Stichococcus sp. (comparable to S. cylindricus BuTCHER) was also used as an experimental organism to test the influence of $\mathrm{Cu}$ and $\mathrm{Li}$ on growth. This organism, together with the flagellate and C. didymus, were isolated by the writer from the Plymouth plankton and subcultured without difficulty in artificial sea water.

It is notable that the results obtained with these organisms support the general conclusions obtained by WILSON (1951), regarding the grading of the different waters as "good" or "bad" for rearing larvae, also the conclusion that the quality of the "bad" water is improved by mixing it with the "good" water. However, the Plymouth water was not always bad, neither was the Celtic water always good; a conclusion which WiLson obtained in later years.

For a more quantitative grading of these different sea waters, we have used as an index the relative growth constant of Chaetoceros didymus, which is a pelagic diatom. The chemical and hydrographical data obtained could not always be used as criteria for describing the biological qualities of the different waters. For example, some of

Table 3

Relative growth constants of Chaetoceros didymus as index of potential bioassay

\begin{tabular}{|lcc|}
\hline Type of water & $\begin{array}{c}\mathrm{k}_{1} \\
\text { (without Cu) }\end{array}$ & $\begin{array}{c}\mathrm{k}_{2} \\
\text { (with traces of } \mathrm{Cu} \text { ) }\end{array}$ \\
\hline Celtic water March & 0.59 & 0.62 \\
Celtic water March + E March $(4: 1)$ & 0.59 & \\
Celtic water March + E E $_{1}$ March $(1: 1)$ & 0.57 & \\
E February + Celtic water March (4:1) & 0.44 & \\
E February & 0.42 & \\
Artificial sea water + soil extract & 0.41 & 0.15 \\
Celtic water May & 0.20 & 0.20 \\
E July & 0.13 & 0.39 \\
Celtic water July & 0.12 & \\
\hline
\end{tabular}


the "bad" waters contain higher phosphates than the so-called "good" water, for this reason, the bioassayed waters were all enriched with equal concentrations of $N, P, F e$. The relative growth constant $\left(\mathrm{k}_{1}\right)$ of Chaetoceros didymus in such waters was computed; $\left(\mathrm{k}_{2}\right)$ is the relative growth constant obtained with addition of traces of $\mathrm{Cu}$. The waters employed could thus be arranged in a descending order as follows (Table 3 ).

It is notable that both Plymouth and Celtic waters collected in March and July were poor in $\mathrm{Cu}$. Their properties had been improved by the addition of traces of $\mathrm{Cu}$ as shown in the table. Artificial sea water with soil extract approaches in quality that of the "good" natural waters as illustrated by the relative growth constant of Chatoceros didymus.

Natural waters could, therefore, be classified according to their suitability for the growth of Chatoceros didymus as follows: (1) Celtic water of March, (2) Plymouth water of February, (3) Celtic water of May, (4) Plymouth water of July, (5) Celtic water of July and (6) Plymouth water of March.

Thus, it becomes evident that not all Celtic waters are good and not all Plymouth waters are bad. It is also clear from Table 3 that mixtures of "good" and "bad" waters improve the qualities of "bad" water, in accordance with the proportions of "good" water added. However, growth declines after a few weeks in such mixtures.

An important quality of the Celtic waters collected in May, July and (to a lesser extent) in March, is the capacity of such waters to induce auxospore formation in Chatoceros didymus cultured in them. This was not the case with the Plymouth waters, in spite of the fact that all these waters were enriched with $\mathrm{N}, \mathrm{P}, \mathrm{Fe}$. This capacity of the Celtic water to induce auxospores in $C$. didymus is inhibited by the addition of traces of $\mathrm{Cu}$.

Our knowledge is scanty of the conditions under which auxospores in centric diatoms are formed in nature. Auxospores usually develop from newly formed zygotes. It has been suggested that a certain size range of cells in diatoms is necessary for meiosis and gamete production, and that such size range is subject to environmental factors (voN STosch 1954, Bruckmayer-Berkenbusch 1955, Erben 1962). However, ERben (1962) states that in Melosira nummuloides, it was not possible either to inhibit or to initiate formation of auxospores by varying the concentrations of $\mathrm{NO}_{3}, \mathrm{PO}_{4}$ or by addition of organic compounds such as dinitrophenol. BRUCKMAYER-BERKENBUSCH (1955) was, however, able to inhibit auxospores in this diatom by continuous illumination at $24^{\circ} \mathrm{C}$.

Soli (1963) suggests a relationship between the presence of bacteria in cultures and formation of auxospores, since he found that in bacteria containing cultures, Chaetoceros didymus formed auxospores in 8 days, while it took longer in cultures without bacteria subjected to the same environmental conditions. From our culture experiments, the role of trace metals could be suggested as a possible factor conditioning auxospore formation; however, this requires further experiments under more controlled conditions.

The addition of traces of $\mathrm{Li}$ to natural or artificial sea water had interesting morphological effects on cells of both Chaetoceros didymus and Stichococcus sp. Cells of both plants became elongated in such media; sometimes, up to 5 times the normal length of cell in $C$. didymus was obtained with $20 \mathrm{mg} \mathrm{Li} / \mathrm{m}^{3}$.

It is interesting in this respect to draw attention to the work of RUNNSTRÖM 
(1935) and others, on the action of this element on sea urchin egg development. The most important changes in this case involve the enlargement of the entomesoderm at the expense of the ectoderm. RunNström has shown that Li penetrates the cells of the sea urchin and has an effect on the animal pole greater than that on the vegetative pole. This element also has an inhibitory action of respiration in sea urchin eggs.

The bioassay of different waters with Phaeodactylum tricornutum gave a similar result to that of Chaetoceros didymus. The waters in which this organism was grown could be arranged (according to the crop obtained) as follows: (1) Celtic water of May, (2) mixture of Celtic water of May and Plymouth water of March, (3) Plymouth water of February and (4) Plymourh water of March.

Phaeodactylum tricornutum seems to be more sensitive to $\mathrm{Cu}$ than Chaetoceros didymus, because its growth was reduced with additions of $10-20 \mathrm{mg} \mathrm{Cu} / \mathrm{m}^{3}$. At higher $\mathrm{Cu}$ concentrations, a long lag period was observed as is the case with $C$. didymus. Cells which survive $\mathrm{Cu}$ toxicity then begin to multiply. This could be ascribed to removal from the water of the excess $\mathrm{Cu}$ by adsorption on dead cells of the diatoms; on bacteria; on glass surface; or even to the chelating properties on the organic metabolites in the medium. These surviving cells could also have become adjusted to higher $\mathrm{Cu}$ concentrations in the medium. SPENCER (1957) found that cupric ions are toxic to Phaeodactylum tricornutum in excess of ca $2 \times 10^{-6} \mathrm{M}$, but with EDTA, this toxicity is at $5 \times 10^{-3} \mathrm{M}$. HAYWARD (1968) also noticed that this imperfect, brackish water diatom may be atypical as compared with the coastal or oceanic members of phytoplankton. Evidence has been obtained that higher $\mathrm{Cu}$ concentrations favour the formation of ovoid cells in this species, and cells tend to aggregate in such concentrations.

Flagellate "A" gave a picture similar to Chaetoceros didymus and Pbaeodactylum tricornutum in the bioassayed waters. This species, however, grew best in artificial sea water with Laminaria ash, and it appears to tolerate higher concentrations of $\mathrm{Cu}$ and Li.

Traces of $\mathrm{Cu}$ inhibit and traces of $\mathrm{Li}$ stimulate the growth of the green alga Stichococcus in artificial sea water. This alga tolerates up to $100 \mathrm{mg} \mathrm{Li} / \mathrm{m}^{3}$. Both flagellate "A" and Stichococcus sp. also grew in artificial sea water made of the major constituents only. Taking into consideration the contamination of the pure chemicals with trace elements, it seems, however, that the growth requirements of these two algae of such elements are limited. PinTer \& Provasoli (1963) grew some chrysomonads in artificial media with no addition of trace elements. They suggested that the trace elements required by such organisms, such as $\mathrm{Cu}, \mathrm{Co}, \mathrm{Zn}, \mathrm{Mn}, \mathrm{Fe}$, are supplied by the impurities brought in by the chemically pure salts of the medium. Such impurities have been incorporated in our artificial sea water.

In an attempt to discover the trace metal requirements of Chatoceros didymus, this species was grown in artificial sea water enriched with $\mathrm{N}, \mathrm{P}, \mathrm{Fe}$ and with additions of individual elements such as $\mathrm{Cu}, \mathrm{Li}, \mathrm{Mn}, \mathrm{Co}, \mathrm{Zn}$, As. The best growth was obtained with the addition of soil extract, which gave far better results than any individual element. In these cultures, no chelating agents were added because, as advocated by Provasoli (1963) and Johnston (1964), chelating agents interfere with the trace element assayed as several other ions are disturbed. Furthermore, as stated by Prova- 
solI, many organic substances which occur in natural waters, such as peptides, amino acids, hydroxy and nucleic acids, can chelate heavy metals in various degrees.

Our culture assays, as previously stated, are nonaxenic. Therefore, vitamins and other organic substances necessary for the growth of the above organisms could thus be made available by the natural bacterial flora associated with these algae. Bacteria, as suggested by PrOVAsoli et al. (1957) may also exercise a beneficial action upon the diatoms with which they grow, by slowly buffering the medium, by influencing the heavy metal solubility or by lowering the oxidation reduction potential of the medium during the early phase of growth, apart from also providing active metabolites.

Such bacteric cultures may reflect a more realistic approach to the characters of the waters assayed. JoHNSTON (1963) employing bacteria free cultures of Skeletonema obtained either no growth or poor growth in over 200 samples of sea water from the North Sea (enriched with N, P, Si, with or without trace metal additions). Evidence was also obtained, which agreed with SPENCER (1954) that ageing of sea water improves its qualities. This is probably due to the adsorption of toxic heavy metals.

\section{SUMMARY}

1. Natural sea water collected at different months from the English Channel at Plymouth and from the Celtic Sea were enriched with N, P, Fe and bioassayed with unialgal cultures of the pelagic diatom Chaetoceros didymus, a reddish flagellate "A" and Phaeodactylum tricornutum.

2. The first two organisms together with the green alga Stichococcus sp. (cf. S. cylindricus BUTCHER) were isolated from the Plymouth plankton and subcultured in artificial sea water, and the Phaeodactylum cornutum was supplied from the strain culture of the Plymouth Laboratory. The relative growth constant of Chaetoceros didymus was taken as an index to classify the different waters according to their suitability for the growth of this diatom. These waters could then be classified in the following order: (a) Celtic sea water of March, (b) Plymouth water of February, (c) Celtic sea water of May, (d) Plymouth water of July, (e) Celtic sea water of July and (f) Plymouth water of March.

3. Mixing of "good" and "bad" waters improved the qualities of the bad water, but growth again declined after 10-15 days.

4. Artificial sea water with soil extract approximates the qualities of "good" natural sea water.

5. Properties of the "bad" or "sterile" waters could be improved by additions of $\mathrm{Cu}$, particularly when this metal in the natural water was impoverished.

6. Celtic Sea waters of May, July and (to a lesser extent) of March, induced auxospore formation in Chaetoceros didymus. This capacity was inhibited by additions of traces of $\mathrm{Cu}$.

7. Li causes elongation of cells in both Chaetoceros didymus and Stichococcus sp. The morphological effects of this element on phytoplankton cells require further studies. 
8. Pbaeodactylum tricornutum and flagellate " $A$ " gave similar results to those of Chaetoceros didymus with regard to the bioassayed waters employed.

9. Phaeodactylum tricornutum and Stichococcus sp. appear to be sensitive to traces of $\mathrm{Cu}$, while the latter species, together with flagellate " $\mathrm{A}$ ", can tolerate high concentrations of $\mathrm{Li}$.

10. Evidence has also been obtained that the ageing of sea water could improve its qualities.

Acknowledgements. I wish to express my indebtedness to the late Dr. W. R. G. Atkins, F.R.S., to Dr. W. H. HARveY, F.R.S., and to Dr. L. N. H. Cooper of the Plymouth Laboratory, Citadel Hill, Plymouth, U.K., for many valuable discussions, also to Sir F. S. Russelt, F.R.S., former Director of the Plymouth Laboratory, for the facilities placed at my disposal. Grateful thanks are due also to Dr. P. DoHrn, Naples, for the extensive use of the Library of the Zoological Station.

\section{LITERATURE CITED}

AlleN, E. J., 1914. On the culture of the plankton diatom Thalassiosira gravida. J. mar. biol. Ass. U.K. 10, 417-439.

- \& Nelson, E. W., 1910. On the artificial culture of marine plankton organisms. J. mar. biol. Ass. U.K. 8, 285-295.

AtkiNs, W. R. G., 1933. The rapid estimation of the copper content of sea water. J. mar. biol. Ass. U.K. 19, 63-66.

Bruchmayer-Berkenbusch, H., 1955. Die Beeinflussung der Auxosporenbildung in Melosira nummuloides durch Außenfaktoren. Arch. Protistenk. 100, 183-211.

Butcher, R. W., 1952. Contribution to our knowledge of the smaller marine algae. J. mar. biol. Ass. U.K. 31, 175-191.

Chu, S. P., 1946. Note on the technique of making bacteria-free cultures of marine diatoms. J. mar. biol. Ass. U.K. 26, 296-302.

Droop, M. R., 1957. Auxotrophy and organic compounds in the nutrition of marine phytoplankton. J. gen. Microbiol. 16, 286-293.

- 1962. Organic micronutrients. In: Physiology and biochemistry of algae. Ed. by R. A. Lewin. Acad. Pr., New York, 141-159.

- (Discussion Leader), 1966. Nutritional factors. In: Marine biology. Proceedings of the 2nd International interdisciplinary Conference, 1962. Ed. by C. H. Oppenheimer. N.Y. Academy of Sciences, New York, 85-112.

Erben, K., 1962. Sporulation. In: Physiology and biochemistry of algae. Ed. by R. A. Lewin. Acad. Pr., New York, 701-710.

FoGG, G. E., 1965. Algal cultures and phytoplankton ecology. The Athlone Press, London, 126 pp.

HaYward, J., 1968. Studies on the growth of Phaeodactylum tricornutum. III. Effect of iron on growth. J. mar. biol. Ass. U.K. 48, 295-302.

Hendey, N. I., 1954. Note on the Plymouth Nitzschia culture. J. mar. biol. Ass. U.K. 33, 335-339.

Johnston, R., 1963. Sea water, the natural medium of Phytoplankton. I. General features. J. mar biol. Ass. U.K. 43, 427-445.

- 1964. Sea water... II. Trace metals and chelation and general discussion. J. mar. biol. Ass. U.K. 44, 87-109.

KYLIN, A., 1943. The influence of trace elements on the growth of Ulva lactuca. K. fysiogr. Sällsk. Lund Förh. 13 (19), 185-192. 
- 1945, The nitrogen sources and the influence of manganese on the nitrogen assimilation of Ulva lactuca. K. fysiogr. Sällsk. Lund Förb. 15 (4), 27-35.

Krun, H., 1941. Biologische Analyse des Meerwassers. K. fysiogr. Sällsk. Lund Förb. 11 (21), $217-232$

- 1943. Über die Enährung von Ulva lactuca. K. fysiogr. Sällsk. Lund Förb. 13 (21), 202-214.

- 1946. Uber den Zuwachs der Keimlinge von Ulva lactuca in verschiedenen Nährflüssigkeiten. K. fysiogr. Sällsk. Lund Förb. 16 (23), 225-229.

Matudarra, T., 1939. The physiological property of sea water considered from the effect upon growth of diatoms, with special reference to its vertical and seasonal changes. Bull. Jap. Soc. scient. Fish 8 (4), 187-193.

PINTNeR, I. J. \& Provasoli, L., 1963. Nutritional characteristics of some chrysomonads. In: Symposium on marine microbiology. Ed. by C. H. Oppenheimer. C. C. Thomas, Springfield, Ill., 114-121.

Provasoli, L, 1958. Nutrition and ecology of protozoa and algae. A. Rev. Microbiol. 12, 279-308.

- 1963. Organic regulation of phytoplankton fertility. In: The sea. Ed. by M. N. Hill. Wiley \& Sons, New York, 2, 165-219.

- Mclaughin, I. I. A. \& Droop, M. R, 1957. The development of artificial media for marine algae. Arch. Microbiol. 25, 392-428.

RunNström, J., 1935. An analysis of the action of Lithium on sea urchin development. Biol. Bull. mar. biol. Lab., Woods Hole 68, 378-384.

RusselL, F. S., 1935. On the value of certain plankton animals as indicators of water movements in the English Channel and North Sea. J. mar. biol. Ass. U.K. 20, 309-332.

Sol., G., 1963. Axenic cultivation of a pelagic diatom. In: Symposium on marine microbiology. Ed. by C. H. Oppenheimer. C. C. Thomas, Springfield, Ill., 122-126.

SPENCER, C. P., 1954. Studies on the cultuie of a marine diatom. J. mar. biol. Ass. U.K. 33, 265-290.

- 1957. Utilization of trace elements by unicellular algae. J. gen. Microbiol. 16, 282-285.

Stosch, H. A. voN, 1954. Die Oogamie von Biddulpbia mobiliensis und die bisher bekannten Auxosporenbildung bei den Centrales. Int. bot. Congr. 8 (Paris), Sect. 17, 58-68.

Sverdrup, H. U., Johnson, M. W. \& Fleming, R. H., 1942. The oceans. Prentice Hall, Englewood Cliffs, N. J., 1087 pp.

VALERA, M. DE, 1940. Note on the difference in growth of Enteromorpha species in various culture media. K. fysiogr. Sällsk. Lund Förb. 10, 52-58.

WIESSNER, W., 1962. Inorganic micronutrients. In: Physiology and biochemistry of algae. Ed. by R. A. Lewin. Acad. Pr., New York, 267-268.

WiLson, D. P., 1951. A biological difference between natural sea waters. J. mar. biol. Ass. U.K. 30, 1-26.

- \& Armstrong, F. A. J., 1952. Further experiments on biological differences between natural sea waters. J. mar. biol. Ass. U. K. 31, 335-349.

- - 1954. Biological differences between seawaters: experiments in 1952. J. mar. biol. Ass. U.K. 33, 347-360.

WiLsoN, D. P., 1958. Biological differences between seawaters; experiments in 1954 and 1955. J. mar. biol. Ass. U. K. 37, 331-348.

- 1961. Biological differences between seawaters: experiments in 1960. J. mar. biol. Ass. U.K. 41, 663-681.

Author's address: Prof. Dr. A. A. Alemm

Stazione Zoologica

Napoli, Italy 